\title{
Relation between posture and spine and pelvis flexibility: a systematic review
}

\author{
Relação entre postura e flexibilidade da \\ coluna e pelve: revisão sistemática
}

\section{Relación entre la postura y la flexibilidad de la columna y la pelvis: revisión sistemática}

\author{
Liliane Martini Araújo, Arthur Antoniolli, Emanuelle Francine Detogni Schmit, \\ Cláudia Tarragô Candotti*
}

Universidade Federal do Rio Grande do Sul (UFRGS), Porto Alegre, RS, Brazil

\begin{abstract}
Introduction: Changes in body structure positioning are associated with muscle flexibility and joint mobility, but evidence of this relationship is still incipient. Objective: To identify evidences of correlation between parameters regarding static body posture in orthostasis and spine and pelvis flexibility and/ or mobility. Methods: Systematic review guided by the PRISMA Statement and the recommendations of the Cochrane Collaboration (PROSPERO: CRD42015026298). A search of the BIREME, EMBASE, PubMed and Science Direct databases was carried out, considering the beginning of the databases until January 16, 2017, with the terms and Boolean operators "posture" AND "spine" OR "pelvis" AND "range of motion, articular" OR "movement". To be included in the review, studies should present observational or clinical
\end{abstract}

*LMA: MS, e-mail: liliaraujofisio@gmail.com

AA: MS, e-mail: tuianto@hotmail.com

EFDS: Doctoral student, e-mail: manu_schmit@hotmail.com

CTC: PhD, e-mail: claudia.candotti@ufrgs.br 
trial methodological designs, have sampled healthy individuals, present correlation or association test results between static posture and mobility/flexibility in the sagittal plane, and be published in Spanish, English or Portuguese. The methodological quality was evaluated by the Downs \& Black scale and evidence by the GRADE system. Results: A total of 5,326 studies were obtained, seven of which were included after the establishment of the eligibility criteria. All studies presented high methodological quality, although a considerable heterogeneity regarding the choice of instruments and evaluation protocols was noted, reflecting contradictory results. Therefore, the present systematic review presents a moderate strength of evidence. Conclusion: No definitive evidence is yet available concerning the possible relationship between body posture and spine and pelvis flexibility and mobility.

Keywords: Posture. Pliability. Spine. Pelvis. Review.

\section{Resumo}

Introdução: Alterações no posicionamento das estruturas corporais podem estar associadas à flexibilidade muscular e à mobilidade articular, mas essas evidências ainda são incipientes. Objetivo: Identificar se existem evidências de correlação entre parâmetros da postura corporal estática em ortostase e a flexibilidade e/ ou a mobilidade da coluna vertebral e da pelve. Métodos: Revisão sistemática direcionada pelo PRISMA Statement e nas recomendações da Colaboração Cochrane (PROSPERO: CRD42015026298). Foram conduzidas buscas nas bases de dados BIREME, EMBASE, PubMed e Science Direct, considerando o início das bases até o dia 16 de janeiro de 2017, com os termos e operadores booleanos "posture" AND "spine" OR "pelvis" AND "range of motion, articular" OR "movement". Para serem incluídos, os estudos deveriam apresentar desenho metodológico observacional ou ensaio clínico, amostra de indivíduos saudáveis, resultado de teste de correlação ou associação entre postura estática e mobilidade/flexibilidade no plano sagital, e redação em idioma espanhol, inglês ou português. A qualidade metodológica foi avaliada pela escala de Downs \& Black e a força de evidência pelo sistema GRADE. Resultados: Foram encontrados 5.326 estudos, sendo sete incluídos após crivo dos critérios de elegibilidade, os quais apresentaram elevada qualidade metodológica. Contudo, é considerável a heterogeneidade no que diz respeito a escolha de instrumentos e protocolos avaliativos. Diante disso, a presente revisão sistemática apresenta moderada força de evidência. Conclusão: Ainda não existem evidências definitivas sobre as possíveis relações entre a postura corporal e a flexibilidade e mobilidade da coluna vertebral e da pelve.

Palavras-chave: Postura. Maleabilidade. Coluna Vertebral. Pelve. Revisão.

\section{Resumen}

Introducción: Los cambios en el posicionamiento de las estructuras corporales pueden estar asociados a la flexibilidad muscular y la movilidad articular, pero estas evidencias todavía son incipientes. Objetivo: Identificar si existen evidencias de correlación entre parámetros de la postura corporal estática en ortostasa y la flexibilidady/o la movilidad de la columna vertebral y de la pelvis. Métodos: Revisión sistemática dirigida por el PRISMA Statement y en las recomendaciones de la Colaboración Cochrane (PROSPERO: CRD42015026298). Se realizaron búsquedas en las bases de datos BIREME, EMBASE, PubMed y Science Direct, considerando el inicio de las bases hasta el 16 de enero de 2017, con los términos y operadores booleanos "posture" AND "spine" OR "pelvis" AND "range de movimiento, articular" OR "movement". Para ser estudios incluidos deben presentar diseño de observación y estudio de muestras de ensayos clínicos de individuos sanos, resultado de la prueba de correlación o asociación entre la postura estática y la movilidad/flexibilidad en el plano sagital, y la escritura en lengua española, inglés o portugués. La calidad metodológica fue evaluada por la escala de Downs \& Black y la fuerza de evidencia por el sistema GRADE. Resultados: Se encontraron 5326 estudios, siendo siete 
incluidos tras el tamizaje de los criterios de elegibilidad, los cuales presentaron elevada calidad metodológica. Sin embargo, es considerable la heterogeneidad en lo que se refiere a la elección de instrumentos y protocolos de evaluación. Por lo tanto, la presente revisión sistemática presenta una moderada fuerza de evidencia. Conclusión: Aún no existen evidencias definitivas sobre las posibles relaciones entre la postura corporal y la flexibilidad y movilidad de la columna vertebral y de la pelvis.

Palabras clave: Postura. Docilidad. Columna Vertebral. Pelvis. Revisión.

\section{Introduction}

Body posture, in a biomechanical concept, can be defined as the alignment or orientation of body segments in order to maintain a vertical position [1]. Complementing this definition, Braccialli \& Vilarta [2] indicate that the American Academy of Orthopedics focuses on issues related to the maintenance of the equilibrium between active (musculotendinous) and passive (osteoarticular and ligamentous) subsystems [3, 4]. Moreover, posture comprises a dynamic relation, in which different tissues adapt in response to stimuli, internal or external, expressing a certain body position $[5,6]$.

Thus, it seems reasonable to accept that changes in the positioning of body structures, or body shape in space, are associated with muscle flexibility and joint mobility $[7,8]$ i.e., the way the individual moves prints "marks" on his/her body that may be either useful or harmful $[9,10]$. When muscles are in equilibrium, they optimize body functioning, leaving useful marks that contribute to a harmonious state, allowing bodily freedom, or, in other words, flexibility and mobility. On the other hand, a muscular imbalance generated by excess activity of a certain muscle or a set of muscles ends up leaving harmful marks, which may prevent one or sets of muscles from exercising their main role, movement [11].

In addition, the intimate connection between the vertebral column and pelvic girdle structures, which integrate the center of the body, a stability region, plays a role in load absorption and dissipation [3]. Thus, in addition to strength and rigidity to maintain intervertebral anatomical relationships and protect neural elements, this connection must also, in contrast, be flexible, in order to allow freedom of movement [12].

Regarding the active subsystem, reductions in extensibility and/or muscle activity may affect the compensatory and exacerbated activity of the passive subsystem [3]. For example, psoas muscle activity may result in pelvic anteversion, with a consequent increase in lumbar lordosis [13], whereas, during predominant ischiatibial activity, the postural reflex probably results in pelvic retroversion [14]. Such modifications, over time, can lead to subsystem adaptations, with consequent adoption of a new posture, reflecting in movement alterations.

It should also be pointed out, conceptually, that flexibility is considered a physical fitness component related to the extensibility of soft tissues [15], which, in association with joint mobility, is considered one of the factors responsible for individual postural differences $[2,9,16,17]$. Furthermore, flexibility and mobility are directly related, and can be considered as either complementary or synonymous [18].

Nevertheless, although some consensus exists regarding the close relationship between body posture and flexibility and mobility $[2,12,16]$, evidence is still incipient, especially with regard to the positioning that the body will adopt, which encompasses the osteomioarticular system. In this sense, the following research question arose: does a relationship between parameters concerning static body posture in orthostasis and flexibility and/or mobility of the spine and pelvis exist? To answer this question, the present study carried out a systematic review to identify the correlation evidence between parameters concerning static body posture in orthostasis and flexibility and/or mobility of the spine and pelvis.

\section{Methods}

\section{Study type}

The present study comprised a systematic literature review [19] directed by the PRISMA Statement [20] and based on the recommendations of the Cochrane 
collaboration [21], registered in PROSPERO under code CRD42015026298'.

Search strategies

In order to identify the studies of interest, the BIREME, EMBASE, PubMed and Science Direct databases were searched, independently and in duplicate, comprising the beginning of the databases until January 16, 2017. The following Boolean terms and operators "posture" AND "spine" OR "pelvis" AND "range of motion, articular" OR "movement" were used. An example of an applied search strategy is displayed in Figure 1.

Figure $\mathbf{l}$ - Search strategy applied at the PubMed database.

\begin{tabular}{ll}
\hline$\# 1$ & "Posture" [mesh] OR "Postures" OR "Static posture" \\
$\# 2$ & "Spine" [mesh] OR "Pelvis" [mesh] OR "Spinal \\
& Movements" \\
\#3 & "Range of Motion, Articular" [mesh] OR "Joint Range \\
& of Motion" OR “Joint Flexibility" OR "Flexibility, Joint" \\
& OR "Range of Motion" OR "Mobility" OR "Flexibility" OR \\
& "Movement" [mesh] \\
\#4 \#1 AND \#2 AND \#3
\end{tabular}

\section{Eligibility criteria}

The following eligibility criteria were established in order to select the studies encompassing this review: studies presenting methodological observational designs or clinical trials, presentation of the test results concerning correlation or association between static posture and mobility (or flexibility) variables in the sagittal plane, evidencing the degree and the meaning of the relation, samples comprising healthy individuals, published in Spanish, English or Portuguese.

Two independent evaluators carried out title and abstract assessments of the studies obtained by the database searches, in order to select those with the potential to meet the eligibility criteria. Subsequently, the selected studies were read in full, where the same reviewers, again independently, included studies that met the eligibility criteria in their entirety. Then, the bibliographic references of the included studies were consulted, to manually find new studies. As in the previous phases, the searches were carried out by the same evaluators, in an independent manner. A consensus among the evaluators was required at all stages, with no third evaluator.

\section{Data extraction}

The two evaluators independently applied a standardized form to extract relevant information from each included study, comprising authors, publication year, sample, software or protocol used for postural assessment and flexibility and/or body mobility, analyzed segments and body planes, and statistical results. This information was then compiled into a final worksheet. Whenever required, the reviewers consulted the original article again, to obtain agreements regarding the extracted information.

\section{Study assessments}

The scale proposed by Downs \& Black [22] was used to assess the methodological quality of the included studies. This evaluation instrument consists in a 27-item checklist, in which applied scale items are assigned a point. When items are not applied, the score is zero. This instrument was applied due to its reproducibility and internal consistency [22], as well as flexibility, capable of assessing both observational studies and clinical trials. When the study being assessed is a clinical trial, all 27 items of the instrument are considered. In contrast, only 12 items are considered for observational studies, pertinent to this type of methodological design (Table 1).

When the assessed study included at least $70 \%$ of the items used for methodological quality assessment, it was considered as presenting high methodological quality [23], while studies with the inclusion of less than $70 \%$ were classified as presenting low methodological quality. As in previous phases, this step was performed independently by two evaluators, and divergences were resolved by consensus.

\section{Evidence strength}

The GRADE system (Grading of Recommendations Assessment, Development and Evaluation) was applied to classify the quality of the evidence and the strength of the recommendation provided by this systematic review, which takes into account the following criteria: systematic review, methodological limitations of the included studies, inconsistency (homogeneity of the studies), whether the studies present direct evidence, the accuracy of the results presented in included studies and if the systematic review presents any publication bias, not including all published studies on the research problem [24].

\footnotetext{
1 (http://www.crd.york.ac.uk/PROSPERO/display_record. asp?ID=CRD42015026298).
} 
Based on the established criteria, a classification regarding level of evidence among the four levels presented by the system is attained, comprising: high quality - it is very unlikely that additional research will change the results presented by the systematic review; moderate quality - further research is likely to have a major impact and may change the results presented by the systematic review; low quality - other research is more likely to have a significant impact and alter the results presented by the systematic review; and very low quality - any estimation of results presented by the systematic review is very uncertain, generating the need for further studies.

\section{Results}

A total of 5,323 studies were obtained from the four searched databases, and another three articles were included in the manual search. Of this total, 516 were duplicates, leaving 4810 studies to be analyzed by title and abstract assessments. At this stage, 4755 studies did not meet the eligibility criteria, with 55 studies remaining to be read in their entirety. Of these, only seven covered all eligibility criteria and were included in the review. Figure 2 displays the flowchart of the study inclusion stages in this systematic review according to PRISMA guidelines [20].

Figure 2 - Flowchart of the study inclusion stages in the systematic review.
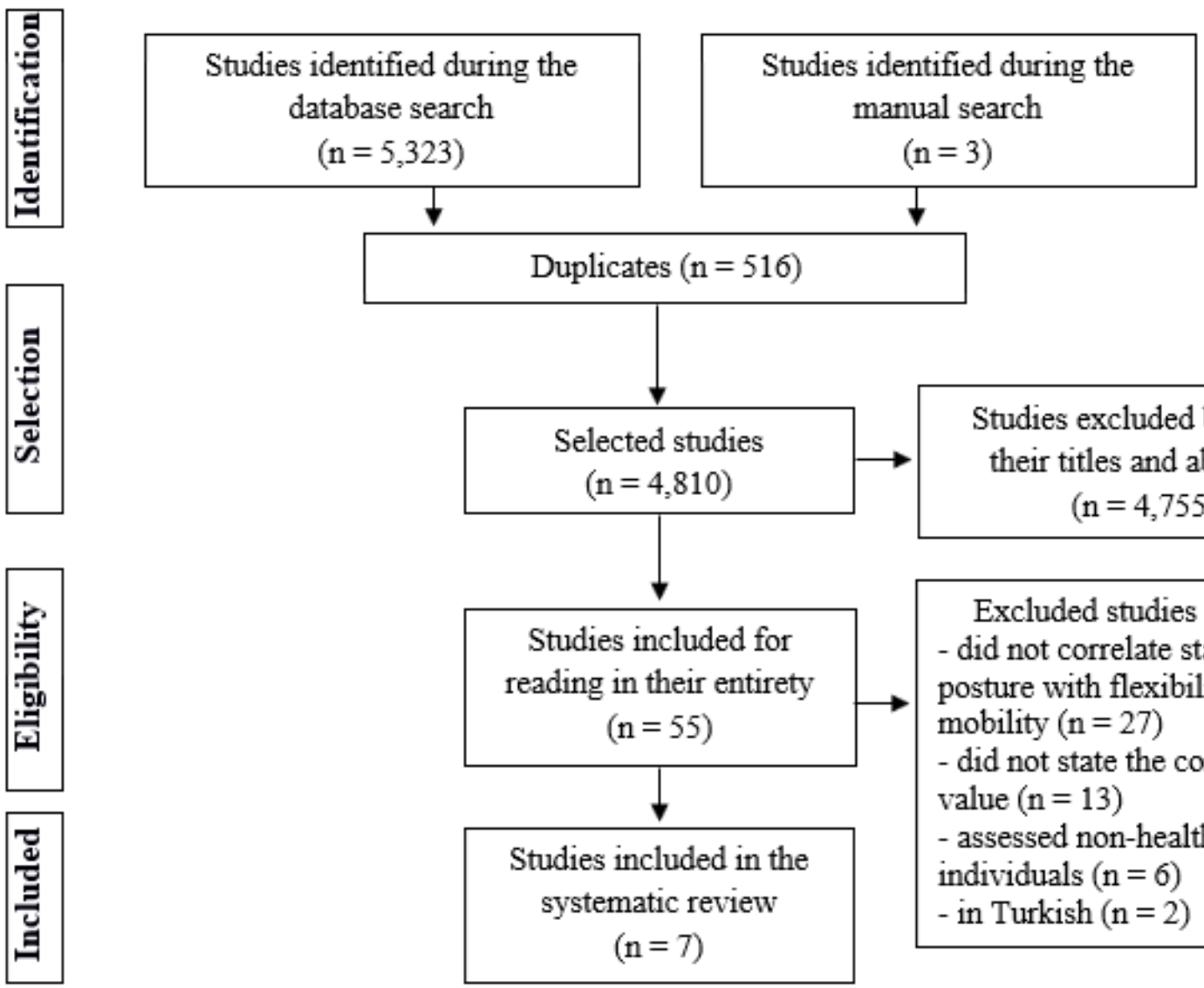
Studies excluded based on their titles and abstracts $(\mathrm{n}=4,755)$

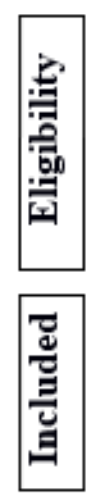

Excluded studies $(n=48)$ - did not correlate static posture with flexibility or mobility $(\mathrm{n}=27)$ - did not state the correlation value $(\mathrm{n}=13)$ - assessed non-healthy individuals $(\mathrm{n}=6)$ - in Turkish $(\mathrm{n}=2)$

The main methodological characteristics of the included studies are presented in Tables 1 and 2, alongside methodological quality assessment information. 
Table 1 - Characteristics of included studies

(to be continued)

\begin{tabular}{|c|c|c|c|c|c|c|}
\hline \multirow{2}{*}{$\begin{array}{l}\text { First author } \\
\text { (year) }\end{array}$} & \multirow{2}{*}{ Sample } & \multicolumn{2}{|c|}{ Postural Assessment } & \multicolumn{2}{|c|}{$\begin{array}{c}\text { Flexibility and/or Mobility } \\
\text { Assessment }\end{array}$} & \multirow{2}{*}{ Result } \\
\hline & & Instrument & $\begin{array}{l}\text { Assessed } \\
\text { segment }\end{array}$ & Instrument & $\begin{array}{l}\text { Assessed segment } \\
\text { and movement }\end{array}$ & \\
\hline $\begin{array}{c}\text { Bridger } \\
\text { (1989) [25] }\end{array}$ & $\begin{array}{c}25 \text { women } \\
(22 \pm 3.2 \\
\text { years old })\end{array}$ & Inclinometer & $\begin{array}{c}\text { Thoracic } \\
\text { (T1/T2 - T12/ } \\
\text { L1) } \\
\text { Lumbar } \\
\text { (T12/L1 - L5/ } \\
\text { S1) }\end{array}$ & Inclinometer & $\begin{array}{l}\text { Lumbar - flexion } \\
\text { and extension } \\
\text { Hips — flexion and } \\
\text { extension }\end{array}$ & $\begin{array}{l}\text { Thoracic } x \text { Hip flexion: } \\
r=-0.42 . p<0.05 \\
\text { Thoracic } x \text { Hip extension: } \\
r=0.36 . p<0.05 \\
\text { Thoracic } \times \text { Hip extension } \\
\text { with flexed knee: } \\
r=0.13 . p>0.05 \\
\text { Lumbar } \times \text { Hip flexion: } \\
r=-0.49 . p<0.05 \\
\text { Lumbar } \times \text { Hip extension: } \\
r=-0.44 . p<0.05 \\
\text { Lumbar } x \text { Hip extension } \\
\text { with flexed knee: } \\
r=-0.34 . p>0.05 \\
\text { Thoracic } x \text { Lumbar } \\
\text { flexion: } r=0.27 . p>0.05 \\
\text { Thoracic } x \text { Lumbar } \\
\text { extension: } \\
r=0.21 . p>0.05 \\
\text { Lumbar } x \text { Lumbar } \\
\text { flexion: } \\
r=-0.17 . p>0.05 \\
\text { Lumbar } x \text { Lumbar } \\
\text { extension: } \\
r=0.03 . p>0.05\end{array}$ \\
\hline $\begin{array}{l}\text { Edmondston } \\
\text { (2011) [26] }\end{array}$ & $\begin{array}{l}40 \text { individuals } \\
\text { (20 men and } \\
20 \text { women; } \\
24 \pm 3.6 \\
\text { years old) }\end{array}$ & $\begin{array}{l}\text { Photogrammetry } \\
\text { (ImageJ software) }\end{array}$ & $\begin{array}{c}\text { Thoracic } \\
\text { (T1- T6 - } \\
\text { T12) }\end{array}$ & $\begin{array}{l}\text { Photogrammetry } \\
\text { (ImageJ } \\
\text { software) }\end{array}$ & $\begin{array}{l}\text { Thoracic - } \\
\text { extension standing, } \\
\text { sitting, prone and } \\
\text { on all fours }\end{array}$ & $\begin{array}{l}\text { Thoracic } \times \text { Standing } \\
\text { thoracic extension: } \\
r=0.63 . p<0.001 \\
\text { Thoracic } \times \text { Sitting } \\
\text { thoracic extension: } \\
r=0.70 . p<0.001 \\
\text { Thoracic } \times \text { Prone } \\
\text { thoracic extension: } \\
r=0.78 . p<0.001 \\
\text { Thoracic } x \text { Thoracic } \\
\text { extension on all fours: } \\
r=0.79 . p<0.001\end{array}$ \\
\hline $\begin{array}{l}\text { Goldberg } \\
(2001)[27]\end{array}$ & $\begin{array}{l}41 \text { individuals } \\
\text { (men and } \\
\text { women; } \\
70.5 \pm 5.3 \\
\text { years old) }\end{array}$ & Goniometer & $\begin{array}{l}\text { Lumbar } \\
(\mathrm{L} 1-\mathrm{S} 2)\end{array}$ & Goniometer & $\begin{array}{l}\text { Lumbar - flexion } \\
\text { and extension }\end{array}$ & 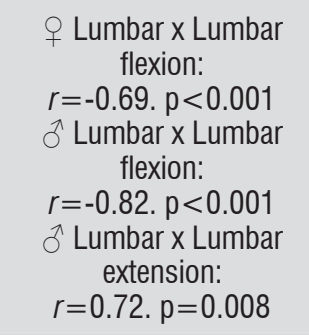 \\
\hline $\begin{array}{c}\text { Muyor } \\
\text { (2013) [28] }\end{array}$ & $\begin{array}{c}75 \text { men } \\
(34.79 \pm 9.46 \\
\text { years old })\end{array}$ & Spinal Mouse & $\begin{array}{c}\text { Thoracic } \\
\text { (T1/2 e } \\
\text { T11/12) } \\
\text { Lumbar } \\
\text { (T12/L1 to } \\
\text { the Sacrum) } \\
\text { Pelvis }\end{array}$ & $\begin{array}{l}\text { Spinal Mouse } \\
\text { and Inclinometer }\end{array}$ & Hamstring muscles & $\begin{array}{c}\text { Thoracic } \times \text { Hamstrings: } \\
r=-0.23 . p=0.001 \\
\text { Lumbar } \times \text { Hamstrings: } \\
r=0.21 . p=0.05 \\
\text { Pelvis } \times \text { Hamstrings: } \\
r=0.37 . p=0.001\end{array}$ \\
\hline
\end{tabular}


Table $\mathbf{1}$ - Characteristics of included studies

(conclusion)

\begin{tabular}{|c|c|c|c|c|c|c|}
\hline \multirow{2}{*}{$\begin{array}{l}\text { First author } \\
\quad \text { (year) }\end{array}$} & \multirow{2}{*}{ Sample } & \multicolumn{2}{|c|}{ Postural assessment } & \multicolumn{2}{|c|}{$\begin{array}{c}\text { Flexibility and/or Mobility } \\
\text { Assessment }\end{array}$} & \multirow{2}{*}{ Results } \\
\hline & & Instrument & $\begin{array}{l}\text { Assessed } \\
\text { segment }\end{array}$ & Instrument & $\begin{array}{c}\text { Assessed segment } \\
\text { and movement }\end{array}$ & \\
\hline $\begin{array}{c}\text { Muyor } \\
\text { (2013) [28] }\end{array}$ & $\begin{array}{c}75 \text { men } \\
(34.79 \pm 9.46 \\
\text { years old })\end{array}$ & Spinal Mouse & $\begin{array}{l}\text { Thoracic } \\
\text { (T1/2 e } \\
\text { T11/12) } \\
\text { Lumbar } \\
\text { (T12/L1 to the } \\
\text { Sacrum) } \\
\text { Pelvis }\end{array}$ & $\begin{array}{c}\text { Spinal } \\
\text { Mouse and } \\
\text { Inclinometer }\end{array}$ & Hamstring muscles & $\begin{array}{c}\text { Thoracic } \times \text { Hamstrings: } \\
r=-0.23 . p=0.001 \\
\text { Lumbar } \times \text { Hamstrings: } \\
r=0.21 . p=0.05 \\
\text { Pelvis } \times \text { Hamstrings: } \\
r=0.37 . p=0.001\end{array}$ \\
\hline $\begin{array}{c}\text { Ohlen } \\
\text { (1988) [29] }\end{array}$ & $\begin{array}{c}64 \text { girls } \\
(11.9 \pm 2.7 \\
\text { years old })\end{array}$ & $\begin{array}{c}\text { Brunner } \\
\text { Kyphometer } \\
\text { and } \\
\text { Inclinometer }\end{array}$ & $\begin{array}{l}\text { Lumbar } \\
\text { (T11/12 - } \\
\text { S1/2) }\end{array}$ & Inclinometer & $\begin{array}{l}\text { Lumbar - flexion, } \\
\text { extension and total }\end{array}$ & 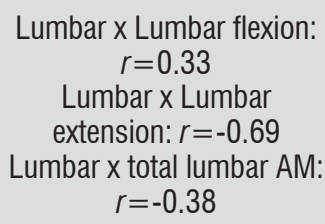 \\
\hline $\begin{array}{l}\text { Toppenberg } \\
\text { (1986) [30] }\end{array}$ & $\begin{array}{l}103 \text { girls } \\
\text { (12.5 to } 16 \\
\text { years old) }\end{array}$ & Inclinometer & $\begin{array}{l}\text { Thoracic } \\
\text { Lumbar } \\
\text { Pelvis }\end{array}$ & $\begin{array}{l}\text { Myrin } \\
\text { Goniometer }\end{array}$ & $\begin{array}{l}\text { Abdominal, } \\
\text { Paravertebrae, } \\
\text { lliopsoas, gluteal, } \\
\text { Rectus femoris and } \\
\text { Hamstring muscles }\end{array}$ & $\begin{array}{c}\text { Thoracic x Paravertebrae: } \\
r=0.016 . p>0.05 \\
\text { Thoracic x Abdominal: } \\
r=-0.245 . p<0.05 \\
\text { Thoracic x lliopsoas: } \\
r=-0.051 . p>0.05\end{array}$ \\
\hline & & & & & & $\begin{array}{l}\text { Thoracic } \times \text { gluteal } \\
\text { muscles: } \\
r=-0.106 . p>0.05 \\
\text { Thoracic } \times \text { Rectus } \\
\text { femoris: } \\
r=0.027 . p>0.05 \\
\text { Thoracic } \times \text { Isquiostibiais: } \\
r=-0.193 . p>0.05 \\
\text { Lumbar } \times \text { Paravertebrae: } \\
r=-0.240 . p<0.05 \\
\text { Lumbar } \times \text { Abdominal: } \\
r=0.209 . p<0.05 \\
\text { Lumbar } \times \text { lliopsoas: } \\
r=-0.196 . p>0.05 \\
\text { Lumbar } \times \text { gluteal muscles: } \\
r=-0.110 . p>0.05 \\
\text { Lumbar } \times \text { Rectus femoris: } \\
r=-0.078 . p>0.05 \\
\text { Lumbar } \times \text { Hamstrings: } \\
r=-0.213 . p<0.05 \\
\text { Pelvis } \times \text { gluteal muscles: } \\
r=-0.014 . p>0.05 \\
\text { Pelvis } \times \text { Rectus femoris: } \\
r=0.131 . p>0.05 \\
\text { Pelvis } \times \text { Hamstrings: } \\
r=-0.026 . p>0.05\end{array}$ \\
\hline $\begin{array}{l}\text { van Adrichem } \\
\text { (1973) [31] }\end{array}$ & $\begin{array}{c}248 \\
\text { individuals } \\
\text { (girls and } \\
\text { boys; } 6 \text { to } 18 \\
\text { years old) }\end{array}$ & $\begin{array}{c}\text { Visual } \\
\text { assessment }\end{array}$ & Lumbar & Schöber test & Lumbar - flexion & $\begin{array}{c}\text { Lumbar } x \text { Lumbar flexion } \\
6 \text { to } 12 \text { years old } \\
0: r=0.008 . p>0.05 \\
\text { s: } r=0.245 . p<0.05 \\
13 \text { to } 18 \text { years old } \\
o: r=0.193 . p>0.05 \\
\text { o }: r=0.232 . p>0.05\end{array}$ \\
\hline
\end{tabular}


Table 2 - Scoring and score of each study in the methodological quality evaluation by the Downs \& Black scale

\begin{tabular}{|c|c|c|c|c|c|c|c|c|c|c|c|c|c|c|c|}
\hline First author (year) & 5 & $\widetilde{\sigma}$ & ஜ & $\mathscr{0}$ & ડ & 8 & 으 & $\mp$ & $\simeq$ & $\dddot{\varphi}$ & $\stackrel{\infty}{\leftarrow}$ & ㅇ & No. of $\sqrt{ }$ & quality \% & $\begin{array}{l}\text { High } \\
\text { quality }\end{array}$ \\
\hline Bridger (1989) [25] & $\sqrt{ }$ & $\sqrt{ }$ & $\sqrt{ }$ & $\sqrt{ }$ & $\sqrt{ }$ & $\sqrt{ }$ & $\sqrt{ }$ & $X$ & $X$ & $\sqrt{ }$ & $\sqrt{ }$ & $\sqrt{ }$ & 10 & 83 & Yes \\
\hline Edmondston (2011) [26] & $\sqrt{ }$ & $\sqrt{ }$ & $\sqrt{ }$ & $\sqrt{ }$ & $\sqrt{ }$ & $\sqrt{ }$ & $\sqrt{ }$ & $\sqrt{ }$ & $X$ & $\sqrt{ }$ & $\sqrt{ }$ & $\sqrt{ }$ & 11 & 92 & Yes \\
\hline Goldberg (2001) [27] & $\sqrt{ }$ & $\sqrt{ }$ & $\sqrt{ }$ & $\sqrt{ }$ & $\sqrt{ }$ & $\sqrt{ }$ & $\sqrt{ }$ & $\sqrt{ }$ & $X$ & $\sqrt{ }$ & $\sqrt{ }$ & $\sqrt{ }$ & 11 & 92 & Yes \\
\hline Muyor (2013) [28] & $\sqrt{ }$ & $\sqrt{ }$ & $\sqrt{ }$ & $\sqrt{ }$ & $\sqrt{ }$ & $\sqrt{ }$ & $\sqrt{ }$ & $\sqrt{ }$ & $X$ & $\sqrt{ }$ & $\sqrt{ }$ & $\sqrt{ }$ & 11 & 92 & Yes \\
\hline Ohlen (1988) [29] & $\sqrt{ }$ & $\sqrt{ }$ & $\sqrt{ }$ & $\sqrt{ }$ & $\sqrt{ }$ & $\sqrt{ }$ & $\sqrt{ }$ & $\sqrt{ }$ & $\sqrt{ }$ & $\sqrt{ }$ & $\sqrt{ }$ & $\sqrt{ }$ & 12 & 100 & Yes \\
\hline Toppenberg (1986) [30] & $\sqrt{ }$ & $\sqrt{ }$ & $\sqrt{ }$ & $X$ & $\sqrt{ }$ & $\sqrt{ }$ & $\sqrt{ }$ & $\sqrt{ }$ & $\sqrt{ }$ & $\sqrt{ }$ & $\sqrt{ }$ & $x$ & 10 & 83 & Yes \\
\hline van Adrichem (1973) [31] & $\sqrt{ }$ & $\sqrt{ }$ & $\sqrt{ }$ & $\sqrt{ }$ & $\sqrt{ }$ & $\sqrt{ }$ & $\sqrt{ }$ & $\sqrt{ }$ & $\sqrt{ }$ & $\sqrt{ }$ & $\sqrt{ }$ & $\sqrt{ }$ & 12 & 100 & Yes \\
\hline
\end{tabular}

Downs \& Black Scale Criteria: 1) Are the purpose and the hypothesis clearly stated? 2) Are the main results to be measured clearly described in the introduction or in the material and methods section? 3) Are the main characteristics of the included individuals clearly described? 6) Are the main findings clearly described? 7) Does the study estimate the data variability in the main findings? 9) Have the characteristics of the lost participants been described? 10) Are the true probability values for the main results presented? 11) Are the subjects invited to participate in the study representative of the population from which they were recruited? 12) Are the subjects prepared to participate in a study representative of the population from which they were recruited? 16) Is it clear if any of the results were based on "data dredging"? 18) Were the statistical tests adequate? 20) Have the measures of the main outcomes been accurate? Answers to the criteria: $\sqrt{ }$ : Yes; $X:$ No.

None of the assessed studies scored $<70 \%$ in the methodological quality assessment, indicating high quality for all included studies (Table 2). Thus, considering the GRADE criteria, the present systematic review presents moderate strength of evidence by summarizing information regarding the correlation between static posture variables and flexibility and the mobility with respect to the vertebral column and pelvis. However, due to the heterogeneity of the studies resulting from methodological divergences, no statistical analysis through a metaanalysis was possible.

\section{Discussion}

Evidence regarding correlations between static body posture parameters (thoracic spine, lumbar spine and pelvis) and spine and pelvis flexibility and mobility are still incipient. Although the studies included in the present review present high methodological quality, a particularly unfavorable methodological heterogeneity is noted, especially regarding the choice of the applied instruments and evaluation protocols.

The inclinometer was the most applied instrument $[25,28,29,30]$, followed by the goniometer $[27,30]$, photogrammetry [26] and the spinal mouse [28], all used for both postural and flexibility and mobility assessments, but presenting protocol variations. Other instruments were also applied for posture assessments, such as visual inspection [31] and kyphometer [29], and the Schöber test to assess flexibility and mobility [31].

Based on the above, the findings of this review demonstrate the lack of an evaluation standard for both postural issues and flexibility and mobility. Concerning spinal evaluations, X-ray examinations, considered by many as the gold standard [32-36], and photogrammetry, which has confirmed validity in relation to the gold standard $[37,38]$, were applied in the included studies, except for the study carried out by Edmondston et al. [26], which only applied photogrammetry. Regarding flexibility assessments, a lack of a standard gold instrument is still noted. Thus, the quality interpretations of assessment protocols must be based on repeatability and reproducibility psychometric indices. In this case, the choice of the inclinometer by the included studies was, in fact, adequate [25, 28-30].

As to the relationship between body posture and flexibility and mobility, there is evidence of alow to moderate correlation between the pelvic and thoracic and lumbar spine angles related to hamstring flexibility. However, these correlations are still incipient to provide definitive 
evidence, since they are controversial in the positive/direct and negative/inverse senses in most studies [25, 28, 30]. It is within this context, to return to anatomical questions in order to favor the understanding of such relationships. As hamstring muscles originate in the hip ischial tuberosity and posterior femur, they can directly interfere in pelvis positioning [39] when shortened or excessively elongated, and, consequently, in the ascending and descending segments, lumbar and knee, respectively [40-43].

Despite the use of different instruments for postural evaluation, the findings reported by Bridger, Wilkinson, Houweninge [25] and Muyor, Miñarro, Alacid [28] are the only ones that agree regarding a thoracic postural relationship with the hamstring musculature, based on moderate to low statistically significant inverse correlations, respectively. Thus, it is possible to speculate that the greater the angular value of the thoracic spine, the lesser the flexibility of the hamstrings, and, consequently, the lower the hip flexion. In addition, the same relation regarding lumbar spine posture is noted $[25,30]$.

Furthermore, based on the studies included in the present review $[25,30]$, results are conflicting regarding the correlation between the lumbar spine and iliopsoas flexibility, since only one of two included studies found a statistically significant inverse correlation [25]. The same study detected a directand significant correlation between thoracic spine and iliopsoas flexibility [25]. In addition, other muscles involved in hip flexibility and mobility, such as the rectus femoris and gluteals, did not present statistically significant correlations with spine posture $[25,30]$.

The relationships between postural variables and the flexibility of the vertebral column itself were also discordant regarding the thoracic region and, thus inconclusive, regarding both trunk extension and flexion, lacking new studies [26, 30]. Toppenberg and Bullock [30] and Ohlen, Wredmark and Spangfort [29] agree on the existence of a significant and inverse correlation with trunk extension movement, even when applying different instruments, restricted to a sample of adolescent girls, suggesting that the greater the static lumbar angle, the lower the flexibility of the lumbar extension movement. This result is explained by Kapandji [44], who describes that the angle of lumbar lordosis in the orthostatic position is already in an extension position, thus diminishing the extension movement. In contrast, Goldberg and Chiarello [27] found a direct correlation between lumbar spine posture and lumbar extension. However, their study sample consisted of elderly individuals, who, due to senility, already display osteomioarticular system involvement.
In addition, the applied lumbar extension measuring method may be questionable, since hip extension at the end of the movement was subtracted [27].

Also for the lumbar region, but regarding flexing, two studies reported an inverse correlation $[27,30]$ and two others, a direct correlation [29, 31]. In a biomechanical analysis of this relation, it would be coherent to say that the lumbar spine presents an inverse relation with lumbar flexion, since, in a standing position, however small the curve, it is the lumbar spine is extended [44]. Nevertheless, when performing the bending movement, if the lumbar is healthy and free, it will make a counter curve [42]. In view of the above, it is important to maintain a healthy relationship between the vertebral column and the pelvic girdle, both in terms of posture and flexibility [45].

It should be noted that, despite the rigorous methodological design adopted in the present study in an attempt to summarize and point out the best evidence concerning the relationship between static body posture and spine and pelvis flexibility and/or mobility, the fact that short and not so current studies were included, with the most recent publication published four years before the search was carried out, is a study limitation, revealing the lack of experimental studies regarding the investigated variables.

\section{Conclusion}

This review indicates lack of definitive evidence on the possible relationships between body posture and spine and pelvis flexibility and mobility. In sum, the results of this systematic review should be interpreted cautiously, considering the divergence of results between the included studies, which may be due to different methodological procedures, and the fact that the understanding of the relationship between posture and spine flexibility is of extreme importance for the clinical context. It is also important to restate the need to carry out new studies that apply gold standard instruments in their assessments and verify sample heterogeneity.

\section{References}

1. Fortin C, Feldman DE, Cheriet F, Labelle H. Validity of a quantitative clinical measurement tool of trunk posture in idiopathic scoliosis. Spine. 2010;35(19):988-94. 
2. Braccialli LMP, Vilarta R. Aspectos a serem considerados na elaboração de programas de prevenção e orientação de problemas posturais. Rev. Paul. Educ. Fís. 2000;14(1):16-28.

3. Panjabi MM. The stabilizing system of the spine. Part I. Function, dysfunction, adaptation and enhancement. J Spinal Disord. 1992;5(4):383-9.

4. Penha PJ, João SMA, Casarotto RA, Amino CJ, Penteado DC. Postural assessment of girls between 7 and 10 years of age. Clinics. 2005;60(1):9-16.

5. Milbradt SN, Pranke GI, Teixeira CS, Lemos LFC, Alves RF, Mota CB. Aspectos da coluna vertebral relacionados à postura em crianças e adolescentes em idade escolar. Rev Fisioter. Bras. 2011;12(2):127-32.

6. Rossi LP, Brandalize M, Gomes ARS. Efeito agudo da técnica de reeducação postural global na postura de mulheres com encurtamento da cadeia muscular anterior. Fisioter. Mov. 2011;24(2):255-63.

7. Widhe T.Spine: posture, mobility and pain. A longitudinal study from childhood to adolescence. Eur Spine J. 2001;10(2):118-23.

8. Marek SM, Cramer JT, Fincher AL, Massey LL, Dangelmaier SM, Purkayastha S, et al. Acute effects of static and proprioceptive neuromuscular facilitation stretching on muscle strength and power output. J Athl Train. 2005;40(2):94-103.

9. Puppin MAFL, Marques AP, Silva AGD, Futuro Neto HA. Alongamento muscular na dor lombar crônica inespecífica: uma estratégia do método GDS. Fisioter Pesq. 2011;18(2):116-21.

10. Díaz-Arribas MJ, Kovacs FM, Royuela A, FernándezSerrano M, Gutiérrez-Fernández L, San MartínPariente 0, et al. Effectiveness of the Godelieve DenysStruyf (GDS) Method in people with low back pain: Cluster Randomized Controlled Trial. Phys Ther. 2015;95(3):319-36.

11. do Rosário JLP, de Sousa A, Cabral CMN, João SMA, Marques AP. Reeducação postural global e alongamento estático segmentar na melhora da flexibilidade, força muscular e amplitude de movimento: um estudo comparativo. Fisioter Pesq. 2008;15(1):12-8.

12. Almeida CCV, Barbosa CGD, Araújo AR, Braga NHM. Relação da fáscia tóraco lombar com o mecanismo ativo de estabilização lombar. Rev. Bras. Ci e Mov. 2006;14(3):105-12.
13. Hodges PW, Richardson CA. Inefficient muscular stabilization of the lumbar spine associated with low back pain. A motor evaluation of transversus abdominis. Spine. 1996;21(22):2640-50.

14. Li Y, McClure PW, Pratt N. The effect of hamstring muscle stretching on standing posture and on lumbar and hip motions during forward bending. Phys Ther. 1996;76(8):836-45.

15. Kloubec JA. Pilates for improvement of muscle endurance, flexibility, balance, and posture. J Strength Cond Res. 2010; 24(3):661-7.

16. Candotti CT, Soares VS, Noll M. A influência da postura sobre as capacidades motoras: agilidade, força e velocidade. Rev. Bras. Ci. e Mov. 2010;18(2):11-18.

17. Noll M, Candotti CT, Vieira A. Escola postural: revisão sistemática dos programas desenvolvidos para escolares no Brasil. Movimento. 2012;18(4):265-91.

18. Basar S, Duzgun I, Guzel NA, Cicioğlu I, Çelik B. Differences in strength, flexibility and stability in freestyle and Greco-Roman wrestlers. J Back Musculoskelet Rehabil. 2014;27(3):321-30.

19. Galvão TF, Pereira MG. Revisões sistemáticas da literatura: passos para sua elaboração. Epidemiol. Serv. Saúde. 2014; 23(1):183-4.

20. Moher D, Liberati A, Tetzlaff J, Altman DG. Preferred reporting items for systematic reviews and metaanalyses: the PRISMA statement. PLoS Med. 2010;6(7): e1000097.

21. Higgins J, Green S. Cochrane handbook for systematic reviews of interventions. Chichester: John Wiley \& Sons, 2011.

22. Downs SH, Black N. The feasibility of creating a checklist for the assessment of the methodological quality both of randomised and non-randomised studies of health care interventions. J Epidemiol Community Health. 1998;52(6):377-84.

23. Silva FF, Carvalho JF. Intensity of anticoagulation in the treatment of thrombosis in the antiphospholipid syndrome: a meta-analysis. Rev Bras Reumatol. 2015;55(2):159-66.

24. Guyatt G, Oxman AD, Akl EA, Kunz R, Vist G, Brozek J, et al. GRADE guidelines: 1. Introduction-GRADE evidence profiles and summary of findings tables. J Clin Epidemiol. 2011;64:383-94. 
25. Bridger R, Wilkinson D, Houweninge TV. Hip joint mobility and spinal angles in standing and in different sitting postures. Hum Factors. 1989;31(2):229-41.

26. Edmondston S; Waller R, Vallin P, Holthe A, Noebauer A, King E. Thoracic spine extension mobility in young adults: influence of subject position and spinal curvature. JOrthop Sports Phys Ther. 2011;41(4):266-73.

27. Goldberg CA, Chiarello CM. Lumbar sagittal plane mobility and lordosis in the well elderly as related to gender and activity level. Phys Occup Ther Geriatr. 2001;19(4):17-34.

28. Muyor JM, Miñarro PAL, Alacid F. The relationship between hamstring muscle extensibility and spinal postures varies with the degree of knee extension. J Appl Biomech. 2013;29(6):678-86.

29. Ohlen G, Wredmark T, Spangfort E. Spinal sagittal configuration and mobility related to low-back pain in the female gymnast. Spine. 1989;14(8):847-50.

30. Toppenberg RM, Bullock MI. The interrelation of spinal curves, pelvic tilt and muscle lengths in the adolescent female. Aust J Physiother. 1986;32(1):6-12.

31. van Adrichem JA, van der Korst JK. Assessment of the flexibility of the lumbar spine. A pilot study in children and adolescents. Scand J Rheumatol. 1973;2(2):87-91.

32. Ribeiro RP, Marchetti BV, Oliveira EBD, Candotti CT. Índice de cifose obtido em radiografia e com o flexicurva na avaliação de crianças e jovens. Rev Bras Saúde Matern Infant. 2017;17(1):79-87.

33. Iunes DH, Bevilaqua-Grossi D, Oliveira AS, Castro FA, Salgado HS. Análise comparativa entre avaliação postural visual e por fotogrametria computadorizada. Rev Bras Fisioter. 2009;13(4):308-15.

34. Chaise FO, Candotti CT, Torre ML, Furlanetto TS, Pelinson PPT, Loss JF. Validation, repeatability and reproducibility of a noninvasive instrument for measuring thoracic and lumbar curvature of the spine in the sagittal plane. Rev Bras Fisioter. 2011;15(6):511-7.

35. Furlanetto TS, Chaise FO, Candotti CT, Loss JF. Fidedignidade de um protocolo de avaliação postural. Rev Educ Fís. 2011;22(3):411-9.

36. Camelo EMPF, Uchôa DM, Uchoa Santos-Junior FF, Vasconcelos TBD, Macena RHM. Use of softwares for posture assessment: integrative review. Coluna/ Columna. 2015;14(3):230-5.
37. Iunes DH, Bevilaqua-Grossi D, Oliveira AS, Castro FA, Salgado HS. Confiabilidade intra e interexaminadores e repetibilidade da avaliação postural pela fotogrametria. Rev Bras Fisioter. 2005;9(3):327-34.

38. Furlanetto TS, Candotti CT, Comerlato T, Loss JF. Validating a postural evaluation method developed using a Digital Image-based Postural Assessment (DIPA) software. Comput Methods Programs Biomed. 2012;108(1):203-12.

39. Gajdosik RL. Passive extensibility of skeletal muscle: review of the literature with clinical implications. Clin Biomech (Bristol, Avon). 2001;16(2):87-101.

40. Davis DS, Ashby PE, McCale KL, McQuain JA, Wine JM. The effectiveness of 3 stretching techniques on hamstring flexibility using consistent stretching parameters. J Strength Cond Res. 2005;19(1):27-32.

41. Coelho JJ, Graciosa MD, de Medeiros DL, da Silva Pacheco SC, da Costa LMR, Ries LGK. Influência da flexibilidade e sexo na postura de escolares. Rev Paul Pediatr. 2014;32(3):223-8.

42. Campignon P. Cadeias Postero-Medianas: cadeias musculares e articulares - método GDS. São Paulo: Summus, 2015.

43. Díaz-Arribas MJ, Sanchez MR, Hervas PP, Chicharro JL, Carrere TA, Molina PO, et al. Effectiveness of the physical therapy Godelive Denys-Struyf method for nonspecific low back pain: primary care randomized control trial. Spine. 2009;34(15):1529-38.

44. Kapandji IA. Fisiologia articular: esquemas comentados de mecânica humana. Rio de Janeiro: GuanabaraKoogan, 2008.

45. Hsu C, Castillo E, Lieberman D. The relationship between trunk muscle strength and flexibility, intervertebral disc wedging, and human lumbar lordoses. THURJ. 2015; 8(1):35-41.
Received in 07/03/2017

Recebido em 03/07/2017

Recibido en 03/07/2017

Approved in 10/29/2018

Aprovado em 29/10/2018

Aprobado en 29/10/2018 